\title{
FIDUCIARY SUITS UNDER RULE 10b-5
}

SEC rule 10b-5 has continually expanded the federal sphere of corporate regulation. The rule's most recent encroachment upon state corporation law involves the derivative suit for breach of fiduciary duties. While the Maytag "deception requirement" temporarily impeded development in this area, the latest cases demonstrate that it no longer precludes $10 b-5$ application. This note analyzes the deception requirement under theories of imputed knowledge, reviews the limitations upon $10 b-5$ use, and posits a developing standard for $10 b-5$ violation.

$\mathbf{R}$ ULE $10 \mathrm{~b}-5,1$ the broad antifraud provision promulgated under the Securities Exchange Act, ${ }^{2}$ has becoine, through judicial interpretation, the inost significaut weapon in the federal antifraud arsenal. ${ }^{3}$ The original purpose of the rule was to extend federal regulation to fraudulent practices by purchasers of securities, ${ }^{4}$ since prior legislation had only encoinpassed the acts of fraudulent sellers. ${ }^{5}$ The need for such extended protection was felt since, under the existing state of the law, corporate insiders could

1 "It shall be unlawful for any person, directly or indirectly, by the use of any means or instrumentality of interstate commerce, or of the mails or of any facility of any national securities exchange, (a) To employ any device, scheme, or artifice to defraud, (b) To make any uutrue statement of a material fact or to omit to state a material fact necessary in order to make the statements made, in light of the circuinstances under which they were made, not misleading, or (c) To engage in any act, practice, or course of business which operates or would operate as a fraud or deceit upon any person, in connection with the purchase or sale of any security." 17 C.F.R. $\$ 240.10 \mathrm{~b}-5$ (1968). The language in part (b) appears to be directed only at the type of omission which would create a "half truth," but has been interpreted by the courts to cover total omissions as well. See Cady, Roberts \& Co., 40 S.E.C. 907 (1961).

${ }^{2}$ Securities Exchange Act of 1934, 15 U.S.C. $\$ 78 \mathrm{~J}$ (1964).

'See generally Fleischer, "Federal Corporation Law": An Assessment, 78 HARv. L. REv. 1146 (1965); Comment, Securities Exchange Act-Statutory Fraud Under Section $10 b$ and Rule X-10b-5, 12 N.Y.L.F. 318 (1966).

4 See Comment, Shareholder Derivative Actions Against Insiders Under Rule 10b-5, 1966 DUKE L.J. 166, at 168.

'Section 17(a) provides: "It shall be unlawful for any person in the offer or sale of any securities...to employ any device, scheme, or artifice to defraud..." 15 U.S.C. $\$ 77 q$ (1964). The section refers to fraud or misrepresentation in the offer or sale of securities. It is perhaps arguable that this language need not be limited to fraud by sellers as distinct from fraud by purchasers, but the SEC has never atteinpted to apply 17(a) except against fraudulent sellers. See 3 L. Loss, Securities Regulation 1424 (2d ed. 1961) [hereinafter cited as Loss]. 
acquire the securities of their corporations by fraudulent means with virtual immunity from federal authority. ${ }^{\circ}$ Rule $10 \mathrm{~b}-5$ has seen its most varied and perplexing applications in cases involving corporate officers or directors. The consistently recurring question has been whether breaches of fiduciary duty to the corporation, ${ }^{7}$ in relation to the purchase and sale of securities, fall within the regulatory ambit of 10b-5. Beginning with Ruckle v. Roto American Corporation, ${ }^{8}$ this note will examine recent fiduciary duty cases with the purpose of isolating the various theories used by the courts to either expand or contract the application of $10 \mathrm{~b}-5$ in this area.

Rule 10b-5 expressly prohibits employment of any seheme, artifice or device to defraud; misrepresentation or omission of any fact material to a purchase or sale, and participation in any fraudulent activity involving a purchase or sale of securities. ${ }^{\circ}$ Because of the need for flexibility, the

1966 DUKe L.J. 168. The spirit behind the passage of the antifraud provisions was expressed by the Supreme Court in SEC v. Capital Gains Research Bureau Inc.: "A fundamental purpose, common to these statutes, was to substitute a philosophy of full disclosure for the philosophy of caveat emptor and thus to achieve a high standard of business ethics in the securities industry.... It requires but little appreciation ... of what happened in this country during the 1920's and 1930's to realize how essential it is that the highest ethical standards prevail." "375 U.S. 180, 186 (1963). It was concluded that "general and flexible" antifraud protections were intended, $I d$. at 199, and the courts have, on the whole, accorded an expansive ambit to 10b-5's literal scope.

${ }^{7}$ Breach of fiduciary duty is a concept arising from common law agency theories. Fiduciary duties generally arise whenever one is placed in a position of trust to another. An action for breach of these duties is available in the innumerable factual situations where the agent acts adversely to the interest of his principal. See generally E. LATTY \& G. Frampton, Basic Business Assoctations 543-78 (1963) [hereinafter cited as LATTY].

Rule 10b-5 fiduciary duties usually arise in two distinct factual contexts: the duty of officers or directors to corporations, and the duty of investunent brokers and advisors to their clients. The courts have generally been most expansive in their application of $10 \mathrm{~b}-5$ to brokers and advisors since the regulation was inost obviously directed at these parties. See, e.g., O'Neill v. Maytag, 339 F.2d 764, 769 (2d Cir. 1964). Fraud is often given a special meaning in actions against investment specialists, without coinmon law limitations being applied. See SEC v. Capital Gains Research Bureau Inc., 375 U.S. 180 (1963); 1967 DUKe L.J. 1061. The use of 10b-5 against corporate officers has not been so broad, and various common law restrictions have been applied. See, e.g., SEC v. Van Horn, 371 F.2d 181 (7th Cir. 1966); Weber v. C.M.P. Corp., 242 F. Supp. 321 (S.D.N.Y. 1965).

339 F.2d 24 (2d Cir. 1964).

- Unlike $\$ 17(a)$ of the Securities Act, Rule $10 \mathrm{~b}-5$ did not expressly provide a civil remedy. However, this disparity was eliminated when an implied civil remedy was recognized in Kardon v. National Gypsum Co., 69 F. Supp. 512 (E.D. Pa. 1946). The court based its finding of a private right of action upon the tort theory that a cause of action exists in favor of those parties whose interests are intended to be protected by the statute. RESTATEMENT (SECOND) OF TORTS $\$ 286$ (1964). 
courts have been reluctant to define the exact elements necessary to constitute a 10b-5 cause of action. ${ }^{10}$ It is generally recognized that the rule extends beyond the restrictive elements of common law fraud, ${ }^{11}$ and actionable deceit has even been defined as the "infinite variety of devices by which undue advantage may be taken ...."12 The common law fraud requirements of deception, causation, and reliance ${ }^{13}$ have been empliasized or ignored, depending upon the policy imterests sought to be protected.

The initial application of the rule in the fiduciary area suggested an expansive use for $10 \mathrm{~b}-5$ in regulating corporate dealings relating to securities transactions, ${ }^{14}$ and the growth of a new area of federal corporation law was predicted. ${ }^{15}$ Against this background of developing federal power, there emerged with $O^{\prime}$ Neill $v$. Maytag ${ }^{16}$ a tendency toward limiting the use of $10 \mathrm{~b}-5$ to situations involving actual fraudulent deception. Breach of fiduciary duties alone was not considered sufficient to constitute a $10 \mathrm{~b}-5$ violation. ${ }^{17}$

The Maytag case involved a stockholders' derivative action ${ }^{18}$ wherein the plaintiff alleged that the corporate directors, in an effort to maintain

${ }^{10} 3$ Loss 1436 . The courts have expressed the fear that, once a strict definition is determined, the unscrupulous will rapidly conceive some means of circumventing it. But see SEC v. Electrogen Indus. Inc., CCH FED. SEC. L. REP. 92,156, at 96,719 (E.D.N.Y. Feb. 26, 1968).

${ }^{22}$ Stevens v. Vowell, 343 F.2d 374, 379 (10th Cir. 1965). The usual justifications for this extended coverage are the intricacy of the subject area, the important public interest in maintaining a stable secnrities market, and the general intent of Congress in the securities acts to provide the SEC with flexible remedial powers.

${ }^{2}$ Cady, Roberts \& Co., 40 S.E.C. 907, 911 (1961).

is See W. Prosser, The LAW of TorTs $\S 100-03$ (3d ed. 1964) [hereinafter cited as Prosser].

"See McClure v. Borne Chemical Co., 292 F.2d 824 (3d Cir.) cert. denied, 368 U.S. 939 (1961). "As implemented by Rule 10b-5 . . Section 10(b) provides stockholders with a potent weapon for enforcenent of many fiduciary duties. It can be fairly said that the Exchange Act ... constitutes far reaching federal substantive corporation law." Id. at 834.

${ }^{15}$ See Ruder, Civil Liability Under Rule 10b-5: Judicial Revision of Legislative Intent? 57 Nw. UL. REv. 627 (1963). But cf. Ruder, Pitfalls in the Development of a Federal Law of Corporations By Implication through Rule 10b-5, 59 Nw. U.L. REv. 185 (1964).

10 339 F.2d 764 (2d Cir. 1964).

${ }^{27}$ Id. at 768.

${ }^{18}$ Most fiduciary duty cases are prosecuted as derivative actions. The theory of the derivative claim is that a stockholder will be permitted to sue on behalf of the corporation for injury suffered by the corporation. See 9 Fletcher, PrIvate CorPoraTIONS $\$ 4469$ (perm. ed. 1965) [hereinafter cited as FlETCHeR]. Therefore, injurious deception of the shareholders as individuals has no bearing upon a $10 \mathrm{~b}-5$ derivative claim. These individual concerns are significant only in a private individual action for 10b-5 fraud. 
their control, negotiated an exchange of stocks with another corporation at an unfavorable ratio. The court noted that, since the directors of both the purchasing and selling corporations had full knowledge of the unfair exchange, there could be no serious claim of deceit. ${ }^{10}$ Relying upon the language of Birnbaum v. Newport Steel Corporation, ${ }^{20}$ the court held that 10b-5 applied only to "that type of misrepresentation or fraudulent practice usually associated with the sale or purchase of securities rather than . . . fraudulent mismanagement of corporate affairs." ${ }^{21}$ In the absence of deception, a breach of fiduciary duty could not constitute a $10 \mathrm{~b}-5$ violation. ${ }^{22}$

The result in Maytag was somewhat surprising in light of the Second Circuit's earlier opinion in Ruckle v. Roto American Corporation. ${ }^{23}$ Ruckle was a stockholder action for injunctive rehef to prevent a stock issuance ${ }^{24}$ at less than value by the directors of the Roto corporation. The court found the issuance to be fraudulent since a minority of the board of directors had not been informed of material facts contained in certain financial statements which would have indicated a higher stock value. The material omissions were found to be sufficient to bring the transaction within the 10b-5 definition of fraud.25 However, the court additionally

${ }^{10} 339$ F.2d at 767.

20 193 F.2d 461 (2d Cir.), cert. denied, 343 U.S. 956 (1952). In addition to requiring that the fraud be of the type "usually associated" with the purchase and sale of securities, Birnbaum also established the "purchaser-seller test." The actual language of 10b-5 prohibits fraud "in connection with the purchase or sale of any sccurity." 17 C.F.R. $\$ 240.10 \mathrm{~b}-5$ (1968). The Birnbaum court interpreted this language to mean that the plaintiffs themselves must have either purchased or sold securities within the meaning of the rule in order to maintain a $10 \mathrm{~b}-5$ action. But see Vine v. Beneficial Finance Corp., 374 F.2d 627 (2d Cir.), cert. denied, 389 U.S. 970 (1967); Voege v. American Sumatra Tobacco Corp., 241 F. Supp. 369 (D. Del. 1965).

${ }^{21} 339$ F.2d at 468.

2 Id.

${ }^{23} 339$ F.2d 24 (2d Cir. 1964). The decision in Ruckle was handed down December 4, 1964. Maytag was decided December 29, 1964. Judge Medina, who wrote the opinion in Ruckle, did not sit on the Maytag case, but Judges Lumbard and Marshall considered both cases. Judge Hays, who replaced Medina, dissented in the Maytag decision, but offered no rationale other than to conclude that a $10 \mathrm{~b}-5$ claim did exist. 339 F.2d at 770.

"An issuance is considered a "sale" for the purposes of Rule 10b-5. Hooper v. Mountain States Sec. Corp., 282 F.2d 195 (5th Cir. 1960), cert. denied, 365 U.S. 814 (1961). It requires an identical volitional element on the part of the corporation. See notes 74-76 infra. The court concluded in Hooper that: "Considering the purpose of this legislation, it would be unrealistic to say that a corporation having the capacity to acquire $\$ 700,000$ worth of assets for its 700,000 shares of stock . . " should not be treated as an injured seller when it actually received nothing. 282 F.2d at 203.

${ }^{25}$ In Ruckle, the Court did not consider the causation question, although it is 
stated that even if all the directors had full knowledge, the corporation could still be considered the victim of deceit. ${ }^{26}$ This dicta directly conflicts with the holding of Maytag that there could be no deceit if the corporate officers of both parties had full information. The development of the case law since the Ruckle and Maytag decisions appears to follow two divergent paths, one of which applies the Maytag rationale, while the other relies upon the Ruckle dicta. Recently this deepening conflict has caused the District Court for the Southern District of New York to question the continued validity of the Maytag approach. ${ }^{27}$

It is important initially to explore the legal theories and policies underlying the Maytag-Ruckle conflict. Both cases articulate the necessity of deceit for a 10b-5 violation. ${ }^{28}$ In Maytag, however, the court found no deceit since the corporate directors of both buyer and seller knew that the stock involved was being exchanged at less than value. The knowledge of the directors was seemingly imputed to the selling corporation, thereby preventing it from being considered the victim of deceit. The Maytag opinion apparently relied upon the universally accepted adage that the "knowledge of directors will be imputed to the corporation," 29 although the opinion contains no express consideration

apparent that the majority of the board could have carried out the transaction over the objections of an informed minority. In Barnett v. Anaconda Co., 238 F. Supp. 766 (S.D.N.Y. 1965), the court was more attentive to the causation requirement, dismissing a 10b-5 claim because the majority could have carried out its injurious plan on its own. However, in Globus, Inc. v. Jaroff, 266 F. Supp. 524 (S.D.N.Y. 1967), the deception of a minority of the voting power was held sufficient to constitute a $10 \mathrm{~b}-5$ violation (as having "some" casual relation). See notes $46-53$ infra and accompanying text.

20 339 F.2d at 29.

${ }^{27}$ See Entel v. Allen, 270 F. Supp. 60 (S.D.N.Y. 1967); Weitzen v. Kearns, [1966-1967 Transfer Binder] CCH FED. SEc. L. REP. I 91,973 (S.D.N.Y. July 20, 1967). See note 95 infra and accompanying text.

"In Ruckle, the court observed that $10 \mathrm{~b}-5$ would apply only if "the board defrauded the corporation imto issuing shares ...."339 F.2d at 29. In Maytag, the court expressly held that "there must be allegations of facts amounting to deception in one form or another; conclusory allegations of deception or fraud will not suffice." 339 F.2d at 768. But cf. notes 104-107 infra and accompanymg text.

${ }^{30} 3$ FLETCHER $\S 790$. This theory is based upon the conclusive presuinption that the director will communicate any material information he receives to his corporation. It is apparent that such a theory is necessary to place the fictional "corporate entity" in the same position as a real person, since, without this imputation, a corporation would be a perennial "bonafide purchaser" and "innocent party." It would otherwise gain the benefit of its directors' knowledge without beiug subjected to any of the liabilities which such knowledge might impose. There are certain requirements which must be met, however, before knowledge will be imputed. Genrally the information must be acquired within the scope of the director's employment, within the time the 
of imputation theory. If the Maytag opinion purports to follow strict imputation doctrine, it would appear to overlook a well-known exception applicable when directors act from some adverse interest. When an interest adverse to that of the corporation is allowed to influence a transaction, director knowledge concerning the transaction will generally not be inrputed to the company. ${ }^{30}$ In Maytag, the directors' interest in seeing the corporate securities exchanged at less than value could easily be construed as adverse to the company's interest in receiving the highest possible value for its stocks. ${ }^{31}$

However, another inputation exception, the "sole actor theory," ${ }_{22}$ may explain the decision in Maytag. The sole actor theory is essentially an exception to the adverse interest rationale. According to this theory, when a director or officer is acting adversely, but is the only party through which the corporation is functioning, his knowledge will be imputed despite

agency existed, and in connection with the particular transaction to which it relates. Id. at $\$ 819$.

${ }^{\text {so } 3}$ FLETCHER at $\$ 819$. The reason offered for this exception is that the agent cannot be presumed to make information known to his principal when that information would injure his own interests. Indeed, the presumption is that the agent will conceal the information. Higgins v. Lansingh, 154 Ill. 301, 40 N.E. 362 (1895). Alternatively, when an agent acts adversely, he is acting outside the scope of his employment, and therefore any knowledge gained should not be imputed. See F. MECHEM, LAW of AGENCY \$ 138 (4th ed. 1952).

Although the adverse interest exception has been well accepted, the courts have been careful not to apply it so as to allow the corporation to evade its proper responsibilities. "A growing tendency is therefore exhibited ... to look beyond the corporate form to the purpose of it, and to the officers who are identificd with that purpose." J.J. McCaskill Co. v. United States, 216 U.S. 504, 515 (1910). "[K]nowledge on the part of the president of a corporation of fraud . . . was imputable to the corporation, where he and his partner ... had the entire management and control ...." 3 FLETCHER $\$ 819$, at 116. See note 33 infra and accompanying text.

s Not every adverse interest is considered sufficient to defeat imputation. Some courts have required a substantial degree of adversity before applying the exception. Sce, e.g., Curtis, Collins \& Holbrook Co. v. United States, 262 U.S. 215 (1923). The Maytag court may not have considered the directors' interest to be sufficiently adverse, since they were profiting only indirectly by maintaining their control, rather than directly through buying the stocks themselves at less than value. Such a narrow view of adversity, however, defeats the policy behind the exception and is not in keeping with the generally accepted test espoused in Fletcher's authoritative treatise on Corporations: "The true test [is] ... whether, in the premises and under all the circumstances of the particular case, the agent's interests are so incompatible with the interests of his principal as practically to destroy the agency or to render it reasonably probable that an ordinary person, in the agent's position, under such circunstances, will neither act in behalf of his primcipal upon his so-acquired knowledge, nor disclose the knowledge to his principal...." 3 FLETCHER $\$ 821$, at 118.

${ }^{2}$ Sce LATTY at 462-67; cf. 3 FLETCHER $\$ 809$. 
his adverse interest. ${ }^{33}$ In Maytag, since the entire board of directors was acting adversely, it could be considered the "sole actor" through which the corporation was able to obtain knowledge. The knowledge of the adverse acting board would then be imputed to the corporation and it would consequently not be considered the victim of deceit. ${ }^{34}$ While not guilty of $10 \mathrm{~b}-5$ fraud under this approach, sole actors injuring their corporations are still liable for their breach of fiduciary duty. ${ }^{35}$ The Maytag court may have deemed it inore advisable to deal with the directors' wrongful activities under common law fiduciary duty prohibitions, ${ }^{36}$

${ }^{33}$ The "sole actor" theory evolved to prevent corporations being operated completely by adverse parties from isolating themselves from losses and liabilities incurred by those actors. A typical situation often involved a bank which was completely dominated by an individual director or group of directors. The bank would accept some property as collateral, the adverse-acting directors having knowledge of a superior security interest in the property. If the debtor failed, the bank would claim to be a bonafide purchaser without notice, arguing that the directors' knowledge should not be imputed since they had acted adversely by accepting burdened collateral. This use of the corporate entity fiction to take advantage of third parties, such as the prior secured creditor in the banking situation, was unacceptable to the courts, and the knowledge of the adverse acting directors was imputed to their corporation. See, e.g. Munroe v. Harriman, 85 F.2d 493 (2d Cir. 1936).

Despite the apparent relevance of the sole actor theory in those cases involving full director knowledge, the Ruckle dicta need not be viewed as pure judicial disregard of an otherwise applicable rule of law so as to expand the operative scope of 10b-5. As previously illustrated, the sole actor rationale is basically an equitable tool utilized to prevent the actions of adverse directors from redounding to the benefit of the corporation at the expense of innocent third parties. Equity, however, does not demand use of the sole actor rule in a Maytag situation. Rather than preventing corporate benefit at the expense of innocent parties, application of the rule in the Maytag context serves only to impede redress of corporate mjury while insulating self-serviug directors from liability under the Exchange Act. Hence, proper respect for the purpose of the sole actor theory wonld foreclose its application in a case such as Maytag.

ss The application of imputation doctrine in Maytag seems to undercut the 10b-5 policy of protecting the investor from intricate securities schemes. Since the "corporate entity" is the investor in the Maytag situation, it is clear that, despite director knowledge it can be made the victim of the type of scheme 10b-5 was intended to prevent if the directors are themselves the schemers and do not use their knowledge to protect their corporation. Public policy, therefore, as well as the adverse interest exception, would appear to require non-imputation in situations such as Maytag.

${ }^{25} 339$ F.2d at 769.

${ }^{39}$ The type of activity under consideration may be subject to control through application of state Blue Sky law or common law fiduciary duty theories, but an action in the federal courts under 10b-5 offers a plaintiff some distinct advantages.

Often private actions for civil liability afford the only real opportunity for enforcement of Blue Sky sanctions. In many states, however, the only remedy provided is recision of the fraudulent transaction. Most states expressly provide protection only for injured buyers, leaving sellers to seek redress solely through com- 
than to classify unconcealed activity as fraud under 10b-5. This sensitivity to common law theory may also have been partly motivated by a desire to keep corporate fiduciary problems out of the federal sphere. ${ }^{37}$

The Ruckle dicta enunciates a position opposite to the restrictive Maytag view. In Ruckle, a minority of the board of directors did not have knowledge of the stock issuance at less than value. In keeping with the adverse interest exception, the knowledge of the directors participating in the scheme was not imputed to the corporation, and a 10b-5 violation was found. Since all of the directors were not involved, the board could not be considered a "sole actor" in order to defeat non-imputation. Therefore, the actual holding of Ruckle is not in conflict with traditional imputation theories. The dicta to the effect that a corporation can be deceived by its entire board of directors, however, relies totally upon the adverse interest exception, ignoring the possible application of the sole actor rule. The court's willingness to reject the fictions of imputed knowledge ${ }^{38}$ suggests a preference for treating overt breaches of fiduciary duty

mon law proceedings. Thus, under the law of many states, an injured corporate seller would not enjoy the type of protection possible under $10 \mathrm{~b}-5$. In addition, most states limit Blue Sky law recovery to amounts paid. While some allow recovery of interest, court costs and attorney fees, only Arizona expressly provides for additional damages. See 3 Loss 1631-38. Rule 10b-5, on the other hand, contains no limitation on damages.

The derivative suit for common law breach of fiduciary duty is also subject to substantial limitations. Often the prosecuting shareholders are initially required to demand satisfaction from the directors, to expressly inform the directors of each detailed cause of action, and to post bond as security for damages arising from corporate defense of the claim. See R. BAKER \& W. CARY, CoRporations 653, 677-81 (3d ed. 1958). A 10b-5 action in the federal courts does not require the shareholders to seek redress from the directors where such action would be futile, FED. R. Crv. P. 23(b). Furthermore, the complaint is governed by the more liberal federal standards of specificity, FED. R. CIV. P. 8(a), the expansive Federal discovery rules are available, see FED. R. CIV. P. 26-37, broad venue provisions and extra territorial service of process may be utilized, Securities Exchange Act $\$ 27,15$ U.S.C. $\$ 78 \mathrm{aa}$ (1964), and often no security bond is required. See Epstein v. Solitron Devices, Inc., CCH FED. SEC. L. REP. If 92,127 (2d Cir. Jan. 11, 1968); Berkwitz v. Humphrey, 130 F. Supp. 142 (N.D. Ohio 1955). But see Cohen v. Beneficial Industrial Loan Corp., 337 U.S. 541 (1949).

${ }^{87}$ See Ruder, Civil Liability Under Rule 10b-5: Judicial Revision of Legislatlve Intent, 57 Nw. U.L. Rev. 627 (1963); Note, 50 CoRNeLl L.Q. 545 (1965).

ss "We come then to the question whether it is possible within the meaning of Section $10(b)$ and Rule $10 \mathrm{~b}-5$ for a corporation to be defrauded by a majority of its directors. We note at the outset that in other contexts, such as embezzlement and conflict of interest, a majority or even the entire board of directors may be held to have defrauded their corporation. When it is practical as well as just to do so, courts have experienced no difficulty in rejecting such cliches as the directors constitute the corporation and a corporation, like any other person, cannot defraud itself." 339 F.2d 
as fraud, rather than allowing the "sole actor fiction" 38 to defeat the $10 \mathrm{~b}-5$ policy of investor protection. ${ }^{40}$

The Maytag-Ruckle conflict contrasts adherence to traditional legal theory with concern for statutory policy. Underlying Maytag is an aversion for classifying open activity as fraud and a desire to treat the adverse activities of corporate directors under traditional state law fiduciary duty concepts. In the background lurks the fear that federal interference with corporate duties would be improper without congressional authorization. ${ }^{41}$ Alternatively, the Ruckle approacl is supported by the 10b-5 policy of protecting the investor from fraudulent scliemes. The Ruckle court was apparently unwilling to see this policy thwarted merely because the imvestor happened to be a corporation subject to the conceptual difficulties surrounding the corporate entity fiction. Underlying the Ruckle view may be a belief that $10 \mathrm{~b}-5$ was intended to pertain to breach of fiduciary duties as well as to traditional fraud. ${ }^{42} \mathrm{~A}$ candid recognition of this idea

at 29 (emphasis added). See 3 FLETCHER $\S 819$. But see 3 FLETCHER $\S 823$, at 128, $\S 824$; cf. LATTY at $462-67$.

${ }^{\infty}$ See note 33 supra and accompanying text.

${ }^{10} \mathrm{~A}$ recent implementation of the Ruckle rationale appeared in Heilbrum v. Hanover Equities Corp., 259 F. Supp. 936 (S.D.N.Y. 1966). In Heilbrunn, a derivative claim was laid against the board of directors for exchanging the corporation's securities for worthless property. Both the corporate directors and the recipients of the securities knew all material facts, but the court, citing Ruckle, held that the corporation could be defrauded by all of its directors, and was not barred from relief by the theories of imputed knowledge. It was recognized that deceit was necessary for a $10 \mathrm{~b}-5$ action, but the deception of the "corporate entity" was found to be sufficient. This non-imputation rationale successfully implements the $10 \mathrm{~b}-5$ policy of protecting the investing corporation, but ignores the sole actor exception to the adverse interest rule, and classifies essentially unconcealed activity as deceit. The adverse activity is clearly overt insofar as the corporation is concerned, since all directors have actual knowledge. However, since the knowledge of adverse acting directors is not to be imputed, the adverse activity is theoretically "concealed" from the corporation. Under this rationale all adverse activities, and therefore all breaclies of fiduciary duty, could be considered "deception" satisfying the requirements of 10b-5.

"See, e.g., Entel v. Allen, 270 F. Supp. 60, 70 (S.D.N.Y. 1967). See also Ruder, Pitfalls in the Development of a Federal Law of Corporations by Implication through Rule 10b-5, 59 Nw. U.L. REv. 185 (1964).

The Entel court displayed this attitude in its quotation of an address by Justice Harlan to the Federal Bar Association:

"[There is an] increasing teudency to look to the federal courts to set right thiugs which, uuder our governmental system, slould be left for solution elsewhere ..... [I]t evinces impatience with the slowness of reform when souglit through the political process, and, what to many is more disturbing, skepticisin as to whether our historic federal system is any longer adequate to meet the problems confronting modern American society. ..." 270 F. Supp. at 70 n.2.

${ }^{4} \mathrm{~J}$ Joseph, Civil Liability Under Rule 10b-5-A Reply, 59 Nw. U.L. REv. 171 
would certainly clear up the conceptual difficulties now generated by manipulation of the theories of imputed knowledge. ${ }^{43}$

Limitation of 10b-5 Use. Subsequent to the Maytag decision, fiduciary cases have consistently voiced reliance upon the Maytag doctrine, although the actual holdings in many have been based upon strong alternative grounds. ${ }^{44}$ The constant attention given to the Maytag requirements in these cases ultimately led to a recognition in Schoenbaum v. Firstbrook ${ }^{45}$

(1964). "II]t is not necessary to consider the rule . . . as either a 'fraud rule' or a 'fiduciary duty rule.' Breaches of fiduciary duty come within the terms of the rule only because the law imposes upon a person occupying a fiduciary position a higher than ordinary standard of duty with respect to his dealings with those for whose benefit he is supposed to act. It is thus ... in a sense both a 'fraud rule' and a 'fiduciary duty rule ...." Id. at 178.

${ }^{43}$ The commentators have disagreed as to the relative merits of extending $10 \mathrm{~b}-5$ into the area of corporate regulation, but some consensus exists for the proposition that the Rule should not be interpreted to cover general breaches of corporate fiduciary duty. See Fleischer, "Federal Corporation Law": An Assessment, 78 HARV. L. REv. 1146,1166 (1965). The opponents of 10b-5 extension object to the "topsey turvey," case by case development of the rule; See Dykstra, Civil Liability Under Rule 10b-5, 1967 UTAH L. REV. 207, 221, and suggest that federal regulation of corporations could better be effected through a careful legislative program. Those who support the socalled common law development of a federal corporation law-suggest that $10 \mathrm{~b}-5$ be viewed as both a "fraud rule and a fiduciary duty rule . . ."; Joseph, Civil Liability Under Rule 10b-5-A Reply, 59 Nw. U.L. REv. 171, 178 (1964), and reject the argument that Congress intended the rule to be limited by the elements of an action based upon common law fraud and deceit. 375 U.S. at 195. The proponents of federal extension focus upon the public policy of insuring fair dealing in the securities market, and suggest that the strictest requirements must be imposed upon those occupying fiduciary positions.

"In Chasin v. Mensher, 255 F. Supp. 545 (S.D.N.Y. 1965), for example, the court noted that the plaintiff was really complaining of a mismanagement of corporate affairs, and suggested that under the Maytag requirement of deception, Rule 10b-5 would not apply. However, ultimate decision of the $10 \mathrm{~b}-5$ issue was reserved, since the plaintiff had not purchased or sold as a result of the mismanagement, and therefore failed to qualify as a proper plaintiff under the Birnbaum rule. See note 20 supra. In Cohen v. Colvin, 266 F. Supp. 677 (S.D.N.Y. 1967), the 10b-5 claim was dismissed beeause the disputed stock was acquired through an amalgamation which could not properly be considered a purchase. The court, however, rationalized its decision under the Maytag dcceit requirement, finding that all directors of both purchaser and seller had full knowledge of the transaction. The plaintiff's reliance on Ruckle was expressly rejected, that case being distimguished on its facts. The opinion in Carliner v. Fair Lanes Inc., 244 F. Supp. 25 (D. Maryland 1965), expressed approval of the Maytag rationale as well as the theory that "the Federal courts should not get involved in working out federal rules to govern every aspect of corporate behavior that involved securities." Id. at 30. The actual holding of the case, however, was based upon the finding that the corporation did not pay an excessive price for the stock and was therefore not damaged.

${ }^{5} 268$ F. Supp. 385 (S.D.N.Y. 1967). In Schoenbaum, the court, quoting extensively from Maytag, seized upon the fact that the directors of both purchaser and 
that the Maytag rule itself was sufficient basis for dismissal of fiduciary duty claims under $10 \mathrm{~b}-5$ in the absence of actual deceit.

However, several other common law theories have also been utilized to restrict $10 \mathrm{~b}-5$ use. ${ }^{46}$ The causation requirement has seen the most frequent application. A $10 \mathrm{~b}-5$ case may present two distinct causation problems. First, a question may arise as to whether a particular injury can be considered a sufficiently direct result of the fraudulent activity. The courts have at times adopted a strict common law theory of causation in order to prevent the finding of a $10 \mathrm{~b}-5$ violation when the imjury was not an immediate and necessary result of the omission or misrepresentation. ${ }^{47}$ Such an approach, however, is not consistent with recent causation

seller had full information, and held that, since there existed no affirmative misrepresentation, no $10 \mathrm{~b}-5$ violation could be found. Ruckle was again distinguished on its facts. The Second Circuit has most recently reviewed the restrictions on $10 \mathrm{~b}-5$ use in Mutual Shares Corp. v. Genesco Inc., [1966-1967 Transfer Binder] CCH FED. SEc. L. REP. I 91,983 (2d Cir. Aug. 14, 1967). In the Mutual case the plaintiff stockholders argued that the seller's failure to reveal intended mismanagement constituted an "implied representation to deal fairly." The court recognized that deception might take the form of non-verbal acts, and that it need not be restricted in any common law sense, but found that the "implied representation not to mismanage" could not be made a valid basis for a 10b-5 action since such an interpretation "would convert any instance of corporate mismanagement into a Rule 10b-5 case." $1 d$. at 96,344. See also Condon v. Richardson, CCH FED. SEc. L. REP. I 92,153 (S.D. III. Nov, 22, 1967) (failure to allege fraudulent or deceitful conduct grounds for dismissal); Levine v. Great Western Sugar Co., CCH FED. Sec. L. REP. g 92,117 (D.N.J. Sept. 29, 1967) (dicta requiring deception, inisrepresentation or some type of fraud).

${ }^{10}$ Considering the various doctrines limiting $10 \mathrm{~b}-5$ use, the court in Mutual Shares Corp. v. Genesco Inc., [1966-1967 Transfer Binder] CCH FED. SEC. L. REP. I 91,983 (2d Cir. Aug. 14, 1967), called attention to the reliance requirement, List v. Fashion Park, Inc., 340 F.2d 457 (2d Cir.), cert. denied, 382 U.S. 811 (1965), causation requirement, Barnet v. Anaconda Co., 238 F. Supp. 766 (S.D.N.Y. 1965). But see Weber v. Bartle, [1966-1967 Transfer Binder] CCH Fed. SEc. L. Rep. I 91,910 (S.D.N.Y. Mar. 20, 1967), and the buyer-seller limitation, Birnbaum v. Newport Steel Corp., 193 F.2d 461 (2d Cir.), cert. denied, 343 U.S. 956 (1952). But see A.T. Brod \& Co. v. Perlow, 375 F.2d 393 (2d Cir. 1967); Vme v. Beneficial Finance Corp., 374 F.2d 627 (2d Cir.), cert. denied, 389 U.S. 970 (1967).

${ }^{17}$ At common law, strict theories of proximate cause expressly limited recovery for misrepresentation. The imjury had to be the direct and foreseeable result of the act sued upon. Hoover v. Allen, 241 F. Supp. 213 (S.D.N.Y. 1965), a 10b-5 case involving omissions of substantial assets from stockholders reports and financial statements, is a recent exainple. In Hoover, the alleged purpose of the omissions was to depress the price of the stock so that the corporation might buy it to aid the directors in maintaining control. The material omissions were clearly recognized, but since the corporation bought at a depressed rather than an infiated price, the absence of injury was fatal to the claim. The plaintiff, anticipating this objection, had alleged that the real injury lay in the waste of corporate assets made possible by the directors gaining 
doctrine. Recovery for misrepresentation will not ordinarily be denied where the fraudulent acts or omissions are a material and substantial factor in bringing about the final injury. ${ }^{48}$ Hence, strict proximate cause requirements for $10 \mathrm{~b}-5$ seem unduly harsh in light of the "substantial factor" test generally utilized in misrepresentation cases.

The most important fiduciary situation in which a $10 \mathrm{~b}-5$ causation issue arises relates to a deception of merely a minority of the board of directors. Where only a minority is deceived, it has often been held that the deception cannot be considered the cause of the injury since the minority lacked the voting power to bring about any differing result.40 This rationale is also vulnerable under the "substantial factor" test. Even though a minority lacks the voting power to block an injurious plan, it could, if informed of the scheme, take other action to prevent its consumation. State law, for example, might be utilized to enjoin or void the objectionable transaction. ${ }^{50}$ Thus, the coneealing of information from a minority should be considered at least a substantial factor in the accomplishment of a fraudulent plan. In Ruckle v. Roto American Corpora$t_{i o n}{ }^{51}$ the deception of a minority was not fatal to the plaintiff's claim,

control. The court held that this waste may have been facilitated by the omissions, but was not directly caused by it, and that therefore no 10b-5 violation could be found.

is The "substantial factor test" is a common method of attempting to articulate the elusive causation requirement of tort law, and has been utilized with greater ease than traditional proximate cause concepts. Under this test, if a particular happening can be termed a "substantial factor," although not the only or even the most significant factor in bringing about a result, that happening will be considered a legal cause of the result. See Prosser § 49, at 286.

In the recent 10b-5 case of Vine v. Beneficial Finance Corp., 374 F.2d 627 (2d Cir.), cert. denied, 389 U.S. 970 (1967), a substantial factor rationale was applied through the finding of a unitary fraudulent scheme which resulted in the final injury. While the very acts sued upon did not cause direct and immediate harm to the plaintiff, they were found to be part of a total fraudulent plan which did bring about injury. The acts could therefore be considered a substantial factor in causing the harm, and 10b-5 recovery could be properly allowed. Id. at 635 .

${ }^{\circ}$ See, e.g., Hoover v. Allen, 241 F. Supp. 213 (S.D.N.Y. 1965); Barnett v. Anaconda Co., 238 F. Supp. 766 (S.D.N.Y. 1965). In Anaconda, the plaintiff alleged that certain proxy statements omitted material facts in order to reduce the apparent value of Wire and Cable stock, thereby inducing the shareholders to sell out for less. Although such omissions satisfied the requirement for deceit, the court noted that the directors had control of more than $73 \%$ of the stock, and could therefore have carricd out the transaction despite minority opposition. Consequently it was held that no 10b-5 violation could be found since the fraud did not cause the sale at less than value.

${ }^{50}$ See note 36 supra.

or 339 F.2d 24 (2d Cir. 1964). In Ruckle, the directors lacking the material information constituted only a minority of the board. It is apparent that the majority had sufficient voting power to carry out their plans, so that the withholding of information 
and, in Globus, Incorporated v. Jaroff, ${ }^{52}$ the court expressly recognized that minority deception bears a sufficient causal relationship to the resulting injury to allow $10 \mathrm{~b}-5$ relief. $^{53}$

The cominon law fraud requirement of scienter has also been applied with great disparity in 10b-5 situations. ${ }^{54}$ Scienter has been defined as covering "everything from knowing falsity with an implication of mens rea, through the various gradations of recklessness, down to such non-action as is virtually equivalent to negligence or even liability without fault . . . " 55 For the purposes of $10 \mathrm{~b}-5$, it has recently been described as the knowledge, or reasonable opportunity to know, that the statements made here were incomplete or untrue. ${ }^{56}$ Cases requiring scienter reason that, without such a requirement, $10 \mathrm{~b}-5$ would basically duplicate the protections of sections 11 and 12 of the Securities Exchange Act,57 without the limited liability and statute of himitations provisions of those sections. ${ }^{58}$

from the minority, although it might well be a material omission, would not seem to be the proximate cause of the mjury under a strict view of causation. The Ruckle court, however, did not address itself to the causation question, perhaps tacitly assuming the existence of "some causal relationship" or applying an unarticulated substantial factor test sufficient to satisfy the more liberal causation theories expressed by the court in Globus Inc. v. Jaroff, 266 F. Supp. 524 (S.D.N.Y. 1967). See note 52 infra.

* 266 F. Supp. 524 (S.D.N.Y. 1967). In Globus, the plaintiff brought a derivative action on the ground that the stockholders had been defrauded into approving a disadvantageous merger deal. Stockholder approval, however, was not actually necessary to confirming the fraudulent sale since the directors controlled over $73 \%$ of the stock and could have approved the deal themselves. The defendant argued that, since stockholder approval was not needed, fraud in obtaining that approval could not be considered the proximate cause of the injury. The court, however, noted that ouly a minority of the "voters" were deceived in Ruckle and held that only some causal relationship was required. Id. at 530. This liberal interpretation of the causation requireinent emphasizes the policy of investor protection and openly recognizes that a deception of even a minority of voters can have causal effect, since a minority could probably raise sufficient pubhic objection to prevent injurious action, even if it technically lacked the voting power to block the activity.

266 F. Supp. 530 (S.D.N.Y. 1967).

" See Weber v. C.M.P. Corp., 242 F. Supp. 321 (S.D.N.Y. 1965); Trussell v. United Underwriters, Ltd., 228 F. Supp. 757 (D. Colo. 1964) (scienter required). But see SEC v. Van Horn, 371 F.2d 181 (7th Cir. 1966); Kohler v. Kohler Co., 208 F. Supp. 808 (E.D. Wis. 1962), aff'd, 319 F.2d 634 (7th Cir. 1963) (scienter not necessary).

${ }^{25} 3$ Loss 1432-3.

${ }^{20}$ Comment, Shareholder Derivative Actions Against Insiders Under Rule 10b-5, 1966 DUKE L.J. 172 n.34.

¿7 15 U.S.C. $\$ 77 \mathrm{k},(1964)$.

${ }^{*}$ See Weber v. C.M.P. Corp., 242 F. Supp. 321 (S.D.N.Y. 1965); Trussell v. United Underwriters, Ltd., 228 F. Supp. 757 (D. Colo. 1964). The recent application of $10 \mathrm{~b}-5$ in an increasing variety of factual instances beyond the scope of sections 11 
On the other hand, cases which dispense with the scienter requirement concentrate on the intent of Congress to provide a new cause of action not limited by the strict requirements of common law fraud. 59

The scienter issue may arise in two varieties of fiduciary duty suits. The first involves the fiduciary duty of an investment broker or advisor to his chent. ${ }^{00}$ The high degree of special duty found in this relationship ${ }^{01}$ has resulted in a fairly hiberal view of the scienter requirement. ${ }^{02} \mathrm{~A}$ second factual instance involves the fiduciary duty of directors to their corporation. Because the apphicability of $10 \mathrm{~b}-5$ to breaches of corporate fiduciary duty has been unclear, due to the deception problem of Maytag, suits of this type have generally not been attempted unless a strong scienter element was apparent. ${ }^{63}$ It would seem, however, that, once the apphicability of $10 \mathrm{~b}-5$ is established, the high degree of loyalty generally required of the corporate fiduciary should result in as loose a scienter requirement as that apphied in the investment situation.

With regard to corporate fiduciary duty cases, the conflict in scienter requirements inay be at least partially rationalized on the basis of factual differences in the cases. Generally, in those cases in which a strict scienter test was articulated, the particular acts in question were of an innocent or unintentional nature, and the court was reluctant to label such acts as fraud. On the other hand, in cases in which a broader form of scienter was recognized, the actors were more clearly behaving wrongfully, and the court was concerned with seeing the violations punished. Hence, it can be posited that the degree of scienter required will seemingly depend upon the apparent unfairness of the acts in question. ${ }^{64}$

and 12 detracts from the argument that without a scienter requirement, mere duplication of coverage would exist. See, e.g., A.T. Brod \& Co. v. Perlow, 375 F.2d 393 (2d Cir. 1967); Vine v. Beneficial Finance Corp., 374 F.2d 627 (2d Cir.), cert. denied, 389 U.S. 970 (1967).

${ }^{20}$ SEC v. Van Horn, 371 F.2d 181 (7th Cir. 1966); Kohler v. Kohler Co., 319 F.2d 634 (7th Cir. 1963).

A major case now pending before the Second Circuit Court of Appeals, SEC v. Texas Gulf Sulphur Co., 258 F. Supp. 262 (S.D.N.Y. 1966), noted in 65 Micri. L. Rev. 944 (1967) and 80 HARv. L. Rev. 468 (1966), may resolve the scienter conflict. The implication of the district court opinion in Texas Gulf Sulphur was that scienter was not mandatory to support the $10 \mathrm{~b}-5$ cause of aetion.

${ }^{\circ}$ See Hughes v. SEC, 174 F.2d 969 (D.C. Cir. 1949).

or See SEC v. Capital Gains Research Bureau, Inc., 375 U.S. 180 (1963).

${ }^{e s}$ See, e.g., Cady, Roberts \& Co., 40 S.E.C. 907 (1961).

See, e.g., Schoenbaum v. Firstbrook, 268 F. Supp. 385 (S.D.N.Y. 1967); Heilbrunn v. Hanover Equities Inc., 259 F. Supp. 936 (S.D.N.Y. 1966).

a Compare Weber v. C.M.P. Corp., 242 F. Supp. 321 (S.D.N.Y. 1965); Trussell v. United Underwriters, Ltd., 228 F. Supp. 757 (D. Colo. 1964) with SEC v. Van Horn, 
Another variation of the scienter question arises with reference to the purpose of the misrepresentation. In two recent cases, Lorenz $v$. Watson ${ }^{65}$ and Howard v. Levine, ${ }^{68} 10 \mathrm{~b}-5$ recovery was denied because certain misrepresentations in government financial statements were not made for the purpose of defrauding stock purchasers, but rather to deceive the government. This utilization of a "purpose" test invokes the strictest form of scienter, bordering on specific imtent. Since a "watered down" form of scienter is all that is usually required under $10 \mathrm{~b}-5,{ }^{67}$ it would seem that misrepresentations knowingly made should be sufficient to constitute violation, regardless of the ultimate purpose behind the untruth. ${ }^{68}$ It may be that the purpose test confuses scienter with those misrepresentation rules governing scope of liability. Traditionally, a party has been hable for misrepresentation only to the class to which the misrepresentation is made. ${ }^{6 \theta}$ Hence, the defendants in Lorenz and Howard might arguably escape liability on the theory that their representations were not made to a class of stock purchasers, rather than on the theory that their purpose was not to deceive this group. The recent tendency in other areas of misrepresentation, however, has been to extend liability even to those whom there is no desire to influence, so long as their reliance on the misrepresentation can reasonably be anticipated. ${ }^{70}$ Adoption of a strict purpose test is, therefore, contrary to the general extension of liability for misrepresentation. Invocation of a purpose test also injects needless confusion into the $10 \mathrm{~b}-5$ area by requiring the courts to deal with yet another fraud concept which, in effect, adds nothing to traditional scienter and scope of liability principles.

The purpose test poses a special danger to $10 \mathrm{~b}-5$ fiduciary suits, since its application could create a convemient loophole for directors whose deceptive activities are only incidental to a broader scheme of

371 F.2d 181 (7th Cir. 1966); Kohler v. Kohler Co., 319 F.2d 634 (7th Cir. 1963); Ellis v. Carter, 291 F.2d 270 (9th Cir. 1961). See also Allico Nat'l Corp. v. Amalgamated Meatcutters, CCH FED. SEC. L. ReP. 92,185 (7th Cir. Apr. 16, 1968) (allegation of wrongful conduct sufficient); SEC v. Texas Gulf Sulphur Co., 258 F. Supp. 262 (S.D.N.Y. 1966) (implication that scienter is not required under 10b-5).

$\approx 258$ F. Supp. 724 (E.D. Pa. 1966).

${ }^{\circ 0} 262$ F. Supp. 643 (S.D.N.Y. 1965).

or 3 Loss 1766.

${ }^{\text {cs See }} 17$ C.F.R. $\S 240.10$ b-5(c) (1968). The use of the language "operates or would operate as a fraud," instead of language concerning intent or purpose, seeins to indicate that schemes which function to defraud are covered, whether or not the fraud is the ultimate purpose of the scheme.

${ }^{\infty}$ See Prosser \$ 102, at 715, 717.

${ }^{70} \mathrm{Id}$. at 718-19. 
maintaining control, and are therefore not committed with a "purpose" to defraud. ${ }^{71}$ Such an application would clearly be contrary to the intended scope of $10 \mathrm{~b}-5$ protection, especially in light of the recent tendency to extend 10b-5 prohibition to the "general fraudulent scheme." 72

A final limitation upon 10b-5 use is the purchaser-seller requirement. The purchaser-seller limitation was initially placed upon $10 \mathrm{~b}-5$ in Birnbaum v. Newport Corporation ${ }^{73}$ which held that, in order to qualify for recovery under 10b-5, a plaintiff must have either purchased or sold securities. Those injured by a sale transaction, but not themselves purchasers or sellers, were denied protection. Crucial to the application of the Birnbaum rule was whether a particular transaction constituted a "sale." The volitional element on the part of the seller became the significant test. ${ }^{74}$ Mergers or stock issuances which required shareliolder approval were considered sales, ${ }^{75}$ while involuntary exchanges of stock, such as short form mergers, were not so considered. ${ }^{78}$ However, in the recent

"See Hoover v. Allen, 241 F. Supp. 213 (S.D.N.Y. 1965).

${ }^{72}$ See Vine v. Beneficial Finance Corp., 374 F.2d 627 (2d Cir.), cert. denied, 389 U.S. 970 (1967); Weber v. Bartle, CCH FED. SEC. L. REP. g 92,158 (S.D.N.Y. Mar. 1, 1968).

73 193 F.2d 461 (2d Cir.), cert. denied, 343 U.S. 956 (1952).

7 See, e.g., Dasho v. Susquehanna Corp., 267 F. Supp. 508 (N.D. Ill. 1966), rev'd, 380 F.2d 262 (7th Cir), cert. denied, 389 U.S. 977 (1967). In Dasho, the district court held that involuntary conversions or "forced sales" subsequent to inerger transactions could not be considered sales for the purposes of $10 \mathrm{~b}-5$ because they were consumated without any voluntary act on the part of the seller. The court of appeals reversed this position, 380 F.2d at 268 , emphasizing the public policy of investor protection.

${ }^{75}$ See, e.g., Globus, Inc. v. Jaroff, 266 F. Supp. 524 (S.D.N.Y. 1967); Simon v. New Haven Board \& Carton Co., 250 F. Supp. 297 (D. Conn. 1966).

${ }^{70}$ See Dasho v. Susquehanna Corp., 267 F. Supp. 508 (N.D. 1ll. 1966), rev'd, 380 F.2d 262 (7th Cir.), cert. denied, 389 U.S. 977 (1967). See also Cohen v. Colvin, 266 F. Supp. 677 (S.D.N.Y. 1967).

A statutory merger, or "short form" inerger, does not require the approval of the shareholders whose stock is being converted into securities of the surviving corporation. A transaction of this type usually requires that the surviving corporation obtain at least $90 \%$ of the outstanding stock of the corporation being acquired. At this time, the remaining outstanding shares are "automatically" converted into the shares of the surviving corporation, without any action on the part of the owners of these outstanding shares. See National Supply Co. v. Leland Stanford Jr. Univ., 134 F.2d 689 (9th Cir.), cert. denied, 320 U.S. 773 (1943). But cf. Vine v. Beneficial Finance Corp., 374 F.2d 627 (2d Cir.), cert. denied, 389 U.S. 970 (1967) ("Sale" found in involuntary merger transaction).

The rationale behind refusing to treat such automatic conversions as "sales" is that they lack the volitional element usually found in a sales transaction. This distinction is somewhat inter-related with the strict causation requirement, since if the 
case of Vine v. Beneficial Finance Corporation, ${ }^{77}$ even an involuntary sale was held sufficient to satisfy the purchaser-seller test. The Vine court reasoned that since the corporation in which the plaintiff owned shares had ceased to exist, he would eventually have to redeem his stock certificates for cash value, thus becoming "party to a sale." 78

Voege v. American Sumatra Incorporated ${ }^{79}$ rehed upon a different approach to circumvent the purchaser-seller requirement. Voege also involved an involuntary inerger, but the plaintiff did not sell or relinquish her stock certificates. The court, however, looked back to the plaintiff's original purcliase of the stock in question, and found an initial inplied representation that the seller would deal fairly. ${ }^{80}$ The subsequent unfair acts were related back to the implied promise of fair dealing in order to qualify the plaintiff as a "deceived purchaser" under 10b-5. While this "relation back" techmique may still be utilized in some situations, the implied representation of fair dealing has recently been criticized and rejected in Mutual Funds Incorporated $v$. Genesco, Incorporated ${ }^{81}$ on the ground that it would cause all unfair transactions subsequent to a stock purchase to be encompassed under 10b-5.

With the elimination of the purchaser/seller test, the scope of 10b-5 coverage will be greatly extended. ${ }^{82}$ Plaintiffs need no longer be parties to a sale. While some kind of exchange will probably still be required, any party whose injury was substantially caused by the fraudulent transaction will be allowed recovery under $10 \mathrm{~b}-5$. Although some may object to this expansion, it must be recognized that the Birnbaum limitation was only a judicial interpretation of the rule and therefore properly subject to judicial alteration. While the language of $10 \mathrm{~b}-5$ specifically forbids fraudulent activities "in conneetion with the purchase or sale," ${ }^{83}$ there is nothing in the language of the rule itself to suggest that other injured parties should be precluded from recovery. Indeed the legislative listory

sale is involuntary, it is difficult to inaintain that a buyer or seller was fraudulently misled imto making it. See notes 47-52 supra and accompanying text.

77374 F.2d 627 (2d Cir), cert. denied, 389 U.S. 970 (1967). See also Dasho v. Susquehanna Corp., 380 F.2d 262 (7th Cir.), cert. denied, 389 U.S. 977 (1967).

374 F.2d at 634 .

241 F. Supp. 369 (D. Del. 1965).

${ }^{\infty} 1 d$. at 375 .

${ }^{81}$ [1966-1967 Transfer Binder] CCH FED. SEC. L. Rep. I 91,983 (2d Cir. Aug. 14, 1967).

${ }^{8} 1967$ Duke L.J. 901. But see Mooney v. Vitolo, CCH FED. SEC. L. REP. I 92,116 (S.D.N.Y. Dec. 7, 1967); Colonial Realty Corp. v. Curtis Publishing Co., CCH FED. SEC. L. REP. I 92,105 (S.D.N.Y. Dec. 4, 1967).

$\bowtie 17$ C.F.R. \& 240.10b-5 (1968). 
and purpose behind section $10 \mathrm{~b}$ suggests that the broadest remedial protection was intended. 84 While the courts have yet to expressly reject the Birnbaum standard, it is clear from the recent cases that a broad remedial approach is being taken. ${ }^{85}$

Extensions of 10b-5 Use. A unique method for avoiding the MaytagRuckle deception problem, and allowing $10 \mathrm{~b}-5$ relief when all directors of a corporation have knowledge of a fraudulent scleine, is the finding of "deceit upon the shareholders as a decision-making body." 86 In situations where shareholder approval is required for a trausaction, deception of the sliareliolders can be treated as if it had been worked upon the directors themselves, simce the shareholders are essentially servimg in the capacity of directors for the purpose of approving the transaction. The deception requirement is therefore satisfied, and 10b-5 recovery may be allowed. Although this approach does provide a rationale for $10 \mathrm{~b}-5$ protection where it is needed, it would allow adverse acting directors to avoid liability by simply seeking another means of impleinenting their injurious plan which did not necessitate shareholder approval. The directors could bring about essentially the same imuries to the corporation and shareholders, while still being shielded by the Maytag deceit requirement, so long as sliareholder approval was not utilized as a means to defraud.

An extension of the decision-making body theory, however, suggests a broad 10b-5 approacl which could encompass all breaches of

st SEC v. Capital Gains Research Bureau, Inc., 375 U.S. 180, 195 (1963).

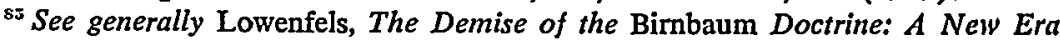
for Rule 10b-5, 54 VA. L. REV. 268 (1968).

${ }^{89}$ See Globus Inc. v. Jaroff, 266 F. Supp. 524 (S.D.N.Y. 1967); Simon v. New Haven Board \& Carton Co., 250 F. Supp. 297 (D. Conn. 1966). In Simon, a derivative action, the plaintiff alleged a $10 \mathrm{~b}-5$ violation in a merger transaction which allowed more than fair value for the stock acquired. Siuce the directors of both "buyer" and "seller" had knowledge of the overallowance, the defendant urged that the necessary elements of deception were lacking. The court, however, focused upon misleading statements concerning the assets of the acquired corporation in the proxy statements prepared for the merger vote. The statements were held to constitute deception of the corporation through its stockholders as the "decision making body." The imputed knowledge of the directors was not considered to bar the corporation from relief. The theory of stockholder deception has thus far been relied upon by the courts only when the shareholders are somehow serving in a decision making capacity; since in this situation the slareholders are essentially serving as directors, it seems entirely reasonable to treat the deception as if it had been worked upon the directors themselves. See also Pappas v. Moss, CCH Fed. SEC. L. Rep. I 92,181 (3d Cir. Apr. $9,1968)$, in which the court suggested that "deception" conld be found by viewing the shareholders as "standing in the place of the defrauded corporate entity...." Id. at 96,878, 
fiduciary duty. It can be argued that the shareholders of a corporation should always be considered a "decision-making body" in reference to corporate stock transactions. If they are aware of an injurious activity, shareholders may be able to react by waging a proxy fight, voting out the directors, or voiding the transaction under state corporation law. ${ }^{87}$ Thus, concealment of directors' breaches would result in stockholder decisions or actions different than would occur if the injurious activity had been revealed. With regard to these decisions, the stockholders could be considered "deceived as the decision-making body." It would then only be necessary for some injury to result from the deception to complete the requirements for a cause of action.

Although this analysis is arguably teuable, and would implement the $10 \mathrm{~b}-5$ policy of investor protection, it suffers from the same faults as the court's play upon doctrines of imputed knowledge. ${ }^{88}$ It is an artificially construed rationale supplied to justify $10 \mathrm{~b}-5$ coverage of fiduciary duties. It would be far less confusing to simply admit that a breach of fiduciary duty itself constitutes a 10b-5 violation, and thus avoid the necessity of sucl judicial maneuvering.

The "implied representation" rationale of Voege v. American Sumatra Incorporated ${ }^{80}$ represents another judicial method for utilizing $10 \mathrm{~b}-5$ in situations involving no actual deceit. In Voege, the requisite 10b-5 deception was found in an implied representation made by the directors to the plaintiff at the time she purchased her stock that they wonld "deal fairly." 80 It is apparent that if such a representation were imphed in every stock purchase, all subsequent unfair acts could be treated under a theory of misrepresentation of intent ${ }^{91}$ at the time of purchase,

${ }^{87}$ See, e.g., Taormina v. Antelope Mining Corp., 110 Cal. App. 2d 314, 242 P.2d 665 (1952). Twenty-five states have provision in their Blue Sky Laws by which a fraudulent stock transaction may be voided on suit by the shareholders. 3 Loss 1632 . Most of these state statutes expressly provide for a right to recision of the fraudulent transaction, and some allow additional recovery for interest, court costs and reasonable attorney's fees. Id. at 1637-38.

${ }^{83}$ See notes 29-33 supra and accompanying text.

241 F. Supp. 369 (D. Del. 1965).

${ }^{\circ 0} I d$. at 375 .

${ }^{21}$ Under the orthodox view there unust be a misrepresentation of fact before recovery for fraud can be allowed. See Prosser $\$ 104$, at 744. If matter other than fact is misrepresented, it is considered not material, or the plaintiff is presumed not to have relied on it. The question then arises whether a representation of intent can be considered one of fact. Lord Bowen's classic view that "The state of man's mind is as much a fact as the state of his digestion," Edgington v. Fitzmaurice, $29 \mathrm{Ch}$. D. 359 (1882), has been accepted in virtually all American jurisdictions. See Prosser 745. The intent or state of mind of a stock purchaser or seller at the time of the transaction 
thus allowing $10 \mathrm{~b}-5$ relief in virtually every situation involving a transfer of securities. Since use of this rationale would result in an impossibly broad ambit of 10b-5 coverage, the implied representation approach has been actively rejected by both the courts and the SEC. ${ }^{22}$

\section{ConCLUSION}

As even a brief perusal of the recent case law will demonstrate, the Maytag-Ruckle deception conflict has injected considerable confusion into the area of $10 \mathrm{~b}-5$ violation. ${ }^{93}$ In attempting to avoid the deception problem, or provide alternative resolutions, tortuous imputation, causation, scienter and purpose theories have been generatcd. A resolution of thc Maytag-Ruckle conflict recognizing openly that breaches of fiduciary duty, while not deceit, will nonetheless be treated as $10 \mathrm{~b}-5$ violations would avoid the necessity for the theories of "constructive deception" which have created so many conceptual difficulties. Once $10 \mathrm{~b}-5$ coverage of the fiduciary area is recognized, the related theories of causation, scienter and purpose may be returned to more traditional roles, since the basic issue of $10 \mathrm{~b}-5$ applicability will be resolved.

can therefore be considered a fact capable of misrepresentation. The Voege approach carries this one step further in that the representation of an intent to deal fairly is implied from the mere existence of a sale transaction.

${ }^{2}$ See Mutual Shares Corp. v. Genesco, Inc. [1966-1967 Transfer Binder] CCH Fed. Sec. L. Rep. I 91,983 (2d Cir. Aug. 14, 1967).

In Genesco, the plaintiff's $10 \mathrm{~b}-5$ claim was classified by the court as complaining that the defeudants impledly represented to the world at large that they would not mismanage the corporation if they acquired control, and that the plaintiffs relied on this when they bought their stock. The SEC in an amicus brief pointed out that any stockholder could plausibly argue that at the time of purchase he relied on an implied representation by management not to inismanage. The Commission argued that if the plaintiff's proposition were accepted, it would convert any instance of corporate mismanagement into a 10b-5 case. See Lester v. Presco Indus., Inc., [1964-1966 Transfer Binder] CCH FED. SEC. L. REP. I 91,562 (S.D.N.Y. 1965).

${ }^{3}$ The question of whether 10b-5 applies to breaches of corporate fiduciary duty has recently given rise to the proposal of Rule 10b-10, SEC Exchange Act Releasc No. 8239 (Jan. 26, 1968), to provide special treatment for such breaches in the specialized area of the imvestment company. The directors of mutual funds and investment companies are often responsible-for wasting fund assets in paying more than value for securities purchased for the fund. See H.R. REP. No. 2337, 89th Cong., 2d Sess. 172 (1966). Since these directors clearly have knowledge of the breach, the applicability of 10b-5 has been questioned because of the absence of deception. See 1967 Duke L.J. 1062. Consequently, Rule 10b-10 has been framed in language specifically prohibiting waste, rather than in the more geueral terms of an antifraud provision. If promulgated, it should provide express fiduciary duty coverage, at least in the specialized area of the investment company. 
One recent case, Entel $v$. Allen, ${ }^{94}$ took a major step toward this resolution of the problem by recognizing that $10 \mathrm{~b}-5$ must now be interpreted to extend to undisclosed breach of state law fiduciary duty. ${ }^{05}$ The Entel court based its somewhat innovative decision upon two recent cases decided by the Second Circuit, A. T. Brod \& Co. v. Perlow ${ }^{96}$ and Vine v. Beneficial Finance Corporation. ${ }^{97}$ In Brod, the district court had relied upon Maytag in dismissing the complaint since it found neither deception as to the value of the stocks, nor any fraud "usually associated

* 270 F. Supp. 60 (S.D.N.Y. 1967), noted in 42 N.Y.U.L. REv. 978 (1967).

${ }^{56} 270 \mathrm{~F}$. Supp. at 70 . In Entel, the court seemed somewhat perplexed with the anomalies of the Maytag-Ruckle conflict. In the first consideration of the derivative claim for sale of stock at less than market value, it was held that no deceit could be claimed since the directors and the buyer had full knowledge. The complaint was therefore dismissed under the Maytag rule for failure to state a cause of action. Upon rehearing, the court reversed its holding, explaining that since its first decision the continued validity of the Maytag rule had been seriously questioned. Id. at 70 . Nevertheless, the wisdom of rejecting the Maytag requirements was questioned on the ground "that the extension of ...10b-5 ... to 'all fraudulent schemes' would be better left to Congress than to judicial interpretation..." $270 \mathrm{~F}$. Supp. at 70. This contention may be criticized on the ground that the Maytag restrictions themselves were judge-made rules and therefore should be subject to judicial cliange without the necessity for legislative action. It can be argued, however, that the accepted judicial interpretation of "fraud" was parainount in the minds of the legislators when they drafted the Securities Exchange Act. To alter the definition of that term so as to encompass breach of fiduciary duty would arguably be a change in the entire scope. rather than merely the interpretation, of the rule. The Maytag-Ruckle conflict was also openly recoguized in Weitznen v. Kearns, [1966-1967 Transfer Binder] CCH FED. SEC. L. REP. 991,973 (S.D.N.Y. July 20, 1967). In Kearns, the plaintiff alleged that the directors of Solitron Corporation issued stock for sale to officers, employees and their families at a value substantially less than its true worth in light of certain rapid profit increases. The defendant, relying on Maytag, argued that 10b-5 did not apply because of the absence of deception. The court recognized that both the directors and the purchasers had true information, but, relying on Ruckle, pointed out that the corporation could be defrauded by all its directors, and that their knowledge would not be imputed to the corporation to prevent it from bringing a $10 \mathrm{~b}-5$ fraud action. It was further suggested that, if the Maytag decision stood for the contrary proposition, it was "seriously challenged, if not overruled." Id. at 96,310. See also Puharich v. Borders Electronics Co., CCH Fed. SEC. L. REP. I 92,141 (S.D.N.Y. Jan. 24, 1968) (Maytag no longer a sound basis for argument).

It should be noted that the approach in Kearns was not to recognize that fiduciary duties were covered under 10b-5, as was done in Entel, but to manipulate the imputation theories along the lines of the Ruckle approach. See notes 29-33 supra and accompanying text.

${ }^{09} 375$ F.2d 393 (2d Cir. 1967). Brod was an action by a stockbroker against a customer who placed orders for various securities, but only paid for those which increased in value by the time paynent was due.

${ }^{\circ 7} 374$ F.2d 627 (2d Cir.), cert. denied, 389 U.S. 970 (1967). 
with the sale or purchase of securities." 98 The court of appeals reversed, stating that the district court had construed $10 \mathrm{~b}-5$ much too narrowly, and that the rule was intended to "prohibit all fraudulent schemes in connection with the purchase or sale of securities, whether the artifices employed involved a garden type variety of fraud, or presented a unique form of deception." 99 While the Brod approach did not abandon the deception requirenrent, it did extend the definition of deception to cover "all fraudulent schemes" without ever attempting to identify any express element of deceit.

In Vine, ${ }^{100}$ the Second Circuit further debilitated the deception requirement. It was the plaintiff's theory in Vine that the directors' use of their fiduciary positions in "shaping the transaction in such a way" that they received inore for their shares than other stockholders constituted a "fraudulent scheme" in violation of 10b-5.101 The defendant, of course, contended that there had been no deceit practiced upon the plaintiff. The court recognized that there had been no representations, statements or communications between plaintiff and defendant, and that the plaintiff could not have rehed in any way upon the defendant, since the sale was involuntary. Attention, however, was directed to prior voluntary sales by shareholders of the plaintiff's class which led to the conditions under which the defendant could force the short form merger. The court found "deception" of the voluntary sellers, but did not articulate the manner of deception, except to indicate that the prior sellers did not have full knowledge of the directors' activities. ${ }^{102}$ The court's reference was presumably to a lack of knowledge on the part of the prior sellers that the directors had breached their fiduciary duty by failing to seek a cash merger through which the shareholders would have received a higher value for their stock. This prior deception, coupled with the subsequent forced sale by the plaintiff, was classified by the court as "part of a single fraudulent schenre," 103 and the coniplaint was held to contain sufficient allegations of deception. Agam, as in Brod, the approach

${ }^{13} 375$ F.2d at 396.

${ }^{\circ 0} \mathrm{Id}$. at 397.

${ }^{100}$ In Vine, the plaintiff alleged that Beneficial conspired with directors of the Crown Corporation, in which the plaintiff owned stock, to merge Crown into Beneficial at a price substantially less than Crown's true worth. The directors owned the controlling stock in Crown and were paid more than value for it by Beneficial. 375 F.2d at $630-31$.

101 374 F.2d at 631 .

100 Id.

${ }^{103}$ Id. at 635: 
of the court was to technically require deception, but then to find such deception in activity which constituted a total fraudulent scheme. The facts of the case were not dissected in order to reveal any express misrepresentation or other traditional fraudulent activity. This approach was actually carried one step further in the Vine case, since the deception was apparently found in a lack of knowledge on the part of prior sellers that fiduciary duties were being breached. Rather than openly recognizing that fiduciary duties fall within the ambit of $10 \mathrm{~b}-5$, the court instead found a nebulous fraudulent scheme, with failure to "reveal" the breach of fiduciary duty constituting the deception. Hence, while deceit is still techmically required under $10 \mathrm{~b}-5$, the recent cases clearly demonstrate that the range of activities which will satisfy the deception requirement has been greatly broadened. It now apparently encompasses breach of fiduciary duty, at least where such breach is "undisclosed," 104 as will almost invariably be the case. ${ }^{105}$

A final resolution of the Maytag-Ruckle question, however, will necessitate a clear determination of deceit requirements by the Second Circuit. The emerging elements of $10 \mathrm{~b}-5$ deceit likely to be required can be gleaned from a survey of the case law. Misrepresentations and omissions of inaterial facts are certainly recognized as 10b-5 deceit. In addition, many factual situations constituting breach of fiduciary duty under state law, such as appropriation of corporate opportunities, waste of corporate assets, misuse of inside information, and general failure to act in the corporation's best interest, now apparently fall within the ambit of $10 \mathrm{~b}-5,106$ where the questionable transaction is related to the purchase or sale of securities. The fraud is to be found in the directors'

201 "If an undisclosed scheme to breach State contract law is encompassed by Section 10 (b) and Rule 10b-5, then an undisclosed scheme to breach State corporate fiduciary law must also be covered. Although the SEC's argument for this interpretation of Section 10 (b) and Rule 10b-5 was rejected in $O^{\prime} N$ eill, it appears to have been adopted in Brod." Entel v. Allen, 270 F. Supp. 60, 70 (S.D.N.Y. 1967).

${ }^{10-}$ Directors would, of course, be unwilling to reveal their breaches of fiduciary duty since, although they might thereby avoid $10 \mathrm{~b}-5$ prosecution, they would leave themselves open to state law derivative suits, as well as possible Blue Sky law action. In addition, such revelations would undoubtedly discredit both the directors and the corporation in the public eye, and substantially effect the value of the corporation's stock.

${ }^{100}$ See Braasch v. Muscat, CCH FED. SEc. L. REP. I 92,148 (S.D.N.Y. Feb. 8, 1968) (plan to siphon off and misappropriate funds could be $10 \mathrm{~b}-5$ violation); Puharich v. Borders Electronics Co., CCH FED. SEC. L. REP. I 92,141 (S.D.N.Y. Jan. 24, 1968) (allegation of manipulative scheme sufficient for 10b-5 cause of action); Ferraiob v. Cantor, CCH FED. SEC. L. REP. I 92,101 (S.D.N.Y. Nov. 29, 1967) (sale by majority at a premium may be $10 \mathrm{~b}-5$ violation). 
failure to reveal their breaches of fiduciary duty to the "corporate entity." As the directors themselves are the "eyes and ears of the corporation," it is difficult to see how they could make their breaches of duty known to the corporate entity, simce their knowledge as directors will not be imputed. ${ }^{107}$ The result is that all breaches of fiduciary duty may be considered "unrevealed," and will therefore constitute material omissions which are a fraud upon the corporation. ${ }^{108}$ The court of appeals may reject this somewhat fictional view of imputed knowledge, however, and openly recognize that breaches of fiduciary duty in the purchase and sale of securities constitute $10 \mathrm{~b}-5$ violations.

The courts seem to be returning to the type of definition expressed in Cady Roberts ${ }^{109}$ that 10b-5 fraud consists of "the infinite variety of devices by which undue advantage may be taken ...." 110 The finding of 10b-5 fraud in Voege v. American Sumatra Corporation was based upon the failure of the defendant "to deal fairly" with the plaintiff.111 Fraud in Vine v. Beneficial Finance Corporation was found to exist in the "shaping [of] the transaction in such a way" that some shareholders received less for their stock than others. ${ }^{112}$ Language in A. T. Brod $v$. Perlow condemning "all fraudulent schemes . . . whether . . . a garden type variety ... or . . . a unique form of deeeption" suggests a broad

\footnotetext{
${ }^{107}$ See notes 29-33 supra and accompanying text.

${ }^{108} \mathrm{~A}$ possible alternative to this conclusion is to impute director knowledge to the corporation, but to find deceit if the breach of fiduciary duty is concealed from the shareholders. See Pappas v. Moss, CCH Fed. SEc. L. Rep. If 92,181, at 96,878 (3d Cir. Apr. 9, 1968) (shareholders viewed as standing in the place of defrauded corporate entity). However, corporate directors have traditionally had no duty to make the corporation's everyday stock transactions known to the shareholders, absent a situation requiring stockholder approval. See R. BAKER, W. CARY, CoRporations 94, 266, 531 (3d ed. 1958). The breach of fiduciary duty situation might, however, be analogized to the "special circumstances doctrine" of Strong v. Repide, 213 U.S. 419 (1909). See also Jennings, Insider Trading in Corporate Securities: A Survey of Hazards and Disclosure Obligations under Rule 10b-5, 62 Nw. U.L. REv. 809 (1968); 20 STAN. L. REv. 347 (1968). In Repide, it was held that directors owe a duty of revelation directly to shareholders if special facts are involved in the transaction. A breach of fiduciary duty might be viewed as such a special fact. Theoretically, under this rationale directors could avoid $10 \mathrm{~b}-5$ violation only by making their intended breaches known to the shareholders. Of course this would seldoun occur, and practically speaking, all breaches of fiduciary duty would be covered under 10b-5. It would seem more realistic to simply admit that $10 \mathrm{~b}-5$ applies to breaches of fiduciary duty as well as fraud, rather than to struggle with principles of imputed knowledge in order to convert the breaches into deceit.

${ }^{100} 40$ S.E.C. 907 (1961).

${ }^{10} I d$. at 911 .

${ }^{112} 241$ F. Supp. 369, 375 (D. Del. 1965).

11374 F.2d 627, 631 (2d Cir.), cert. denied, 389 U.S. 970 (1967).
} 
prohibition of unfair activities. ${ }^{113}$ Application of an "ethical unfairness" test, ${ }^{114}$ whether couched in terms of imputation theory, or shrouded in the cloaks of a general fraudulent scheme, appears to be the emerging vehicle for interpreting securities fraud "not technically and restrictively, but flexibly to effectuate its remedial purposes." 115

${ }^{113} 375$ F.2d 393, 397 (2d Cir. 1967). See also Allico Nat'l Corp. v. Amalgamated Meatcutters, CCH Fed. Sec. L. Rep. I 92,185 (7th Cir. Apr. 16, 1968) (allegation of "wrongful conduct" sufficient to state 10b-5 cause of action).

${ }^{214}$ See Note, The Downstairs Insider: The Specialist and Rule 10b-5, 42 N.Y.U.L. Rev. 695, 705 (1967); Comment, A New Concept of Fraud on the Securities Exchange, 15 S.C.L. REv, 557, 570 (1963). While this ethical unfairness test has been questioned for failing to provide any definitive standard, see A. BROMBERG, SECuRITIEs LAW: FRAUD SEC RULE 10b-5 I 4.7 (1967), and allowing too inuch discretion on the part of the courts in determining fairness, it certainly provides fair warning that the highest degree of ethical conduct is expected. The courts have traditionally refrained from laying down an iron-clad definition of fraud for the express purpose of maintaining sufficient flexibility to cover the latest innovations. See 3 Loss 1436. The fairness test is true to this policy and avoids any possible conflict between state and federal law which might arise if $10 \mathrm{~b}-5$ violation were dependent upon whether an act constituted breach of state law flduciary duty. Otherwise, results might vary from state to state depending upon the fiduciary duty theories entertained in the particular jurisdiction. This result would clearly be detrimental to the regulation of a national securities market requiring uniform Federal control. Although the "unfairness" standard is certainly susceptible to some valid criticisms, it appears to be the best articulation to date of a workable $10 \mathrm{~b}-5$ test.

215375 U.S. at 195. 